\title{
Fatty acids and hydrocarbons in surficial sediments of Lake Huron*
}

\author{
Philip A. Meyfrs and Norishige Takeuchi \\ Department of Atmospheric and Oceanic Science, The University of Michigan, Ann Arbor. \\ MI 48109, U.S.A.
}

(Received 26 June 1978: accepted in retised form 18 September 1978)

\begin{abstract}
Fatty acid and hydrocarbon distributions in surficial sediments from ten locations in southern Lake Huron indicate both aquatic and terrigenous recent biological sources of these geolipid materials. Normal alkanoic acids appear to be derived primarily from aquatic sources whereas normal alkanes are from multiple origins. Geolipid distributions are determined by the nature of the biogenic source and are modified during transport and deposition. Sediments receiving urban runoff in Saginaw Bay contain large amounts of non-biogenic hydrocarbons of a petroleum or industrial nature.
\end{abstract}

\section{INTRODUCTION}

AN IMPORTANT aspect of lipid biogeochemical investigations is to provide information about the sources of organic matter contained within sediments. Most studies of this nature have investigated ancient sediments with the goal of characterizing the organic sources in prehistoric depositional environments. However, it is useful to study the contemporary organic geochemistry of sedimentary environments in order to contribute to a better understanding of materials found in ancient sediments. Furthermore, organic matter in modern sediments is not far removed, if at all, from biological processes and is therefore important for ecological reasons.

Of the several classes of geolipids, fatty acids and hydrocarbons have been investigated more commonly in contemporary sediments, particularly in those studies which have compared the constituents of different sedimentary environments. Major differences in both fatty acid concentration and composition were found by Farrington and Quinn (1973) in surficial sediments from different areas of Narragansett Bay, Rhode Island. Concentrations decreased with increasing distance from urbanized sources of organic matter, and the abundance of palmitoleic acid relative to that of palmitic acid increased over the same distance. Brooks et al. (1976) found bimodal distributions of $n$-alkanoic acids in surficial sediments from temperate lakes and sub-tropical coastal marine locations. Cranwell (1974) interpreted such distributions ats indicative of a blend of short-chain acids from ayuatic sources and of long-chain acids from land sources. Furthermore, the relative contributions of these two types of fatty acid sources to lake sediment organic matter is linked to the biological productivity of overlying waters and to erosion rates within the lake watersheds (Cranwell. 1974).

* Contribution Number 250 of the Department of Atmospheric and Oceanic Science.
The distribution of $n$-paraffins was determined in a sample of coastal marine sediment by Clark and Blumer (1967) in an attempt to identify the sources of these hydrocarbons. Sufficient differences were found between sediment $n$-paraffins and those in benthic and planktonic algae to rule out these potential sources as major contributors. Palacas et al. (1976) measured total alkane distributions of surficial sediments from different coastal locations along the eastern Gulf of Mexico. Gearing et al. (1976) examined distributions of both aliphatic and aromatic hydrocarbons from surficial sediments from continental shelf areas farther offshore than those investigated by Palacas et al. (1976). Larger amounts of $C_{2}$, and $C_{29}$ $n$-alkanes plus unresolved complex mixtures of saturated hydrocarbons in samples close to the Mississippi delta suggested a terrigenous source composed of a combination of higher plant plus fossil fuel alkanes for much of these hydrocarbons. whereas a marine source was indicated by high $n-C_{1}$ - concentrations in samples off Florida. Total saturated hydrocarbon distributions were determined in sediments from three Washington lakes by Wakeham (1976). A large unresolved component was found in the sample from Lake Washington, which has its watershed in metropolitan Seattle, while virtually none was present in the sample from pristine Lake Quinalt. This difference, coupled with different n-alkane distributions. suggests a portion of the hydrocarbons in Lake Washington is petroleum hydrocarbons derived from urban runoff (Wakeham. 1977a, 1977b). Farrington and Tripp (1977) were able to deduce from n-alkane distributions and from the amounts of unresolved complex mixtures of aliphatic hydrocarbons that petroleum sources contribute to the total hydrocarbons present in New York Bight surface sediments and that land-derived hydrocarbons comprise a major portion of $n$-alkanes in marine sediments from continental shelf, slope, and abyssal plain areas. In a similar study, Keizer et al. (1978) determined from 
$n$-alkane and isoprenoid alkane distributions that biogenic terrestrial sources contributed the majority of hydrocarbons found in Scotian Shelf surficial sediments. From aliphatic hydrocarbon and sterol analysis of Mono Lake surficial sediments, Reed (1977) concluded that detrital organic debris from land sources predominates slightly over organic matter derived from lake biota in the total organic composition of these sediments.

Based upon published reports that indicate that geolipid distributions can be used to identify sources of organic input to subaqueous sediments, we initiated an investigation into the sources of organic materials in the sediments of Lake Huron using this approach. This report gives the results of our study of fatty acid and hydrocarbon distributions.

\section{EXPERIMENTAL PROCEDURES}

Samples of surficial sediments from hydrocarbon and fatty acid analysis were collected in 1975 from two transects across the Goderich Basin of southern Lake Huron and from one transect along the axis of Saginaw Bay. The Goderich Basin is bounded by land on the east and by the mid-lake Ipperwash Scarp on the west. This scarp divides lower Lake Huron into the Goderich and Port Huron Basins (Hough,
1958). Sampling locations are shown in Fig. 1. At each of these locations, the top $5 \mathrm{~cm}$ of sediment was obtained and homogenized prior to transfer to solvent-rinsed glass jars and storage at $-20^{\circ} \mathrm{C}$ until analysis. Although sediment texture was estimated. no actual grain size measurements were made in this study. Other investigations have described grain size distributions in surficial sediments from southern Lake Huron (Thomas et al., 1973) and from Saginaw Bay (Wood, 1964). All samples were wet-sieved through a $1 \mathrm{~mm}$ screen prior to subsequent analysis.

Total organic carbon (TOC) was determined for each sample after treating with $1 \mathrm{~N} \mathrm{HCl}$ to remove carbonates and drying to constant weight at $60 \mathrm{C}$. A Hewlett-Packard Model 185B CHN Analyzer was used. Triplicate analyses on several samples yielded an average coefficient of variation of $3.7^{\circ}$ around the mean.

Extraction of fatty acids and hydrocarbons was accomplished using a saponification procedure adapted from one recommended by Farrington and Quinn (1971). Thawed samples were refluxed for I hr in a mixture of $0.5 \mathrm{~N} \mathrm{KOH}$ in $95^{\circ}$ methanol/benzene, 1:1. Non-saponifiable geolipids, including hydrocarbons, were separated from saponifiable materials by adding water to the cooled saponification solvent mixture and extracting with petroleum ether. After

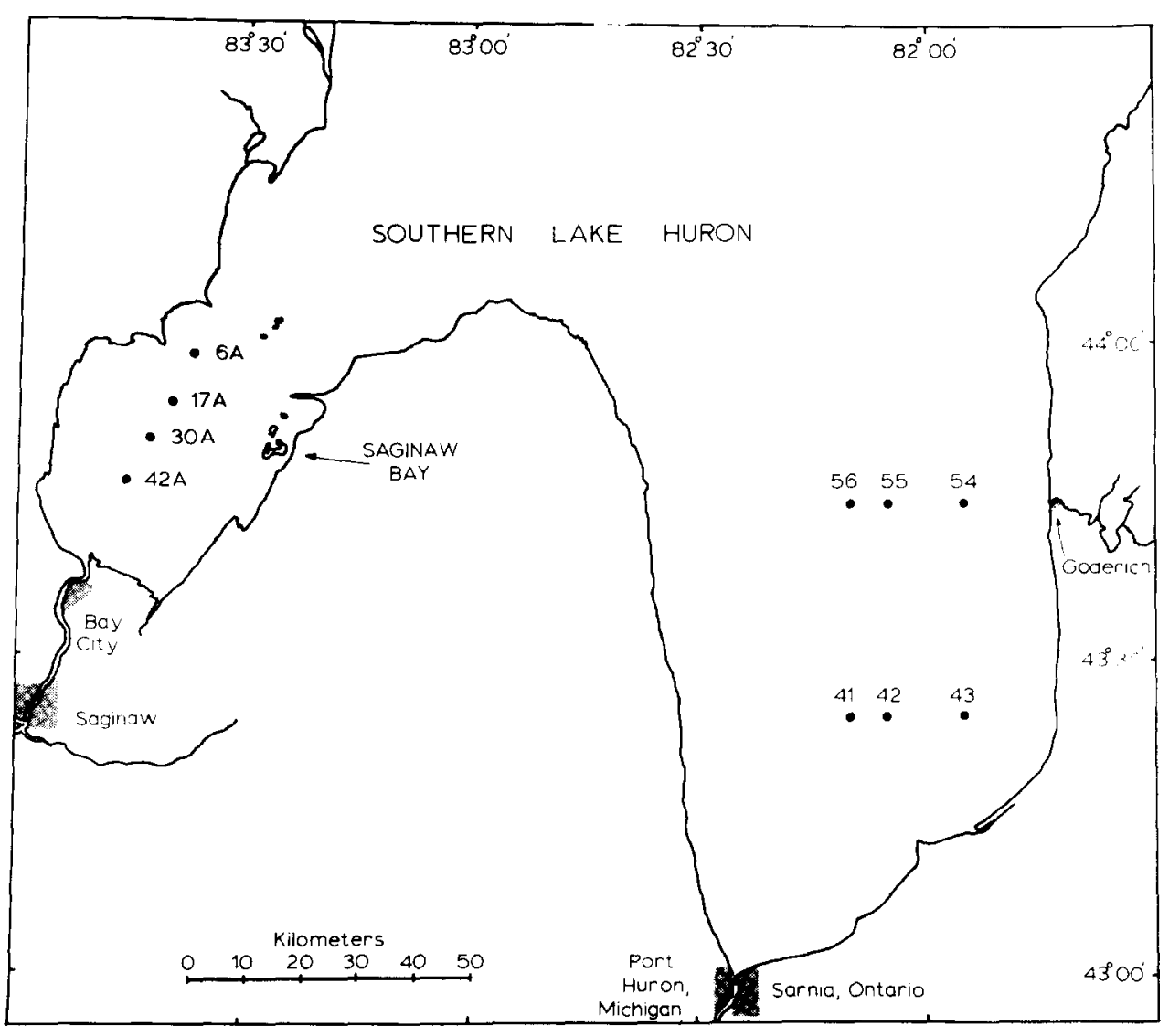

Fig. 1. Chart of southern Lake Huron and Saginaw Bay showing locations of surficial sediment samples and major urban areas and rivers. 
this separation, the aqueous phase was acidified and saponifiable geolipids, including fatty acids, were extracted with petroleum ether.

Hydrocarbons were isolated from other nonsaponifiable geolipids by column chromatography after passing the entire dissolved extract through copper to remove elemental sulfur (Blumer, 1957). The column was packed with alumina over silica gel, both $5 \%$ deactivated and had a height:diameter ratio of $9: 1$. The first column fraction, eluted with petroleum ether, contained saturated and mono-unsaturated hydrocarbons. The second fraction, eluted with benzene, contained polyunsaturated and aromatic hydrocarbons and is called unsaturated hydrocarbons in this paper.

Fatty acids were isolated by methylating the dried residue of the saponifiable geolipid extract using a $\mathrm{BF}_{3}-\mathrm{MeOH}$ procedure patterned after that of Metcalfe et al. (1966). The residue was transferred to a $50 \mathrm{ml}$ screwcap tube in $10 \mathrm{ml}$ benzene:methanol, $1: 1$ and $5 \mathrm{ml} \mathrm{BF}{ }_{3}-\mathrm{MeOH}$ (Supelco Inc., Bellefonte, PA) was added. The tube was sealed and then heated at $100^{\circ} \mathrm{C}$ for $5 \mathrm{~min}$. The resulting fatty acid methyl esters were extracted with petroleum ether and purified by thin-layer chromatography on silica gel $G$ (Merck) plates.

Gas chromatography of hydrocarbons and fatty acid esters was done with a Hewlett-Packard 5830A Reporting Chromatograph. Samples were analyzed with two different types of columns to improve identification of individual components. The columns used for hydrocarbons were $3 \mathrm{~m} \times 2.1 \mathrm{~mm}$ ID $3 \% \mathrm{SP} 2100$ (Supelco Inc.) on 100/120 mesh Supelcoport operated between 150 and $330^{\circ} \mathrm{C}$ at $4 \% \mathrm{~min}$ and $2.5 \mathrm{~m} \times 2.1 \mathrm{~mm}$ ID $10^{\circ} \mathrm{SP} 1000$ (Supelco Inc.) on $80 / 100$ mesh Supelcoport operated between 120 and $250^{\circ} \mathrm{C}$ at $8^{\circ} / \mathrm{min}$. Fatty acid methyl esters were analyzed on the same SP2100 column used for hydrocarbons and also on $2 \mathrm{~m} \times 2.1 \mathrm{~mm}$ ID $10 \%$ SP216 (Supelco Inc.) on 100/120 mesh Supelcoport operated between 150 and $190^{\circ} \mathrm{C}$ at $4 / \mathrm{min}$. All analyses were performed dual differentially to minimize baseline shift at high temperatures and with hydrogen FID detectors. Nitrogen carrier gas flows were adjusted daily to optimize column efficiencies.

Identification of hydrocarbons and fatty acids was done by comparison of sample peak retention times with those of authentic standards. Amounts of these geolipids were determined by electronic integration of peak areas and comparison to the area of a quantitative standard on the same chromatograph. Corrections were made for FID response differences among each class of compounds and for errors introduced by electronic integration.

The overall extraction and analytical efficiencies for triplicate samples of spiked sediments were $90 \pm 6 \%$ for saturated hydrocarbons, $96 \pm 6 \%$ for unsaturated hydrocarbons and $98 \pm 6 \%$ for fatty acids, Procedural blanks showed negligible amounts of contaminants as determined by gas chromatography.

\section{RESULTS}

Table 1 summarizes fatty acid and hydrocarbon data obtained from surficial sediment samples. Levels of fatty acid in the Goderich Basin samples range from 13.2 to $126.8 \mu \mathrm{g}$ total acids per gram dry sediment. Concentrations of total normal alkane hydrocarbons and of total unsaturated hydrocarbons are also presented. These range from 1.6 to 12.8 and from 2.2 to $46.5 \mu \mathrm{g} / \mathrm{g}$, respectively. As shown in Fig. 2. saturated hydrocarbon distributions are characterized by a number of resolved peaks overlying an unresolved complex mixture (UCM) of hydrocarbons. In the Goderich Basin sediments. concentrations of these unresolved hydrocarbons are between 16.1 and $381.7 \mu \mathrm{g} / \mathrm{g}$.

In Saginaw Bay sediments fatty acid concentrations have a narrow range, between 95.8 and $116.8 \mu \mathrm{g} / \mathrm{g}$. which is due in part to the relatively uniform sediment grain size of the four samples. Concentrations of both saturated and unsaturated hydrocarbons are higher in the Saginaw Bay samples than in the Goderich Basin samples, even though the central basin samples have equivalent or higher levels of total organic carbon. Normal alkanes are present at levels of from 19.9 to $27.5 \mu \mathrm{g} / \mathrm{g}$, while unsaturated hydrocarbons range from 73.0 to $176.0 \mu \mathrm{g} / \mathrm{g}$. Unlike the fatty acids and resolved hydrocarbons which exhibit relatively uniform concentrations, UCM amounts in these sediments increase from $349.4 \mu \mathrm{g} / \mathrm{g}$ near the mouth of inner Saginaw Bay to $2669.0 \mu \mathrm{g} / \mathrm{g}$ near the head of the Bay.

In Table 2, the distances from nearest land for each of the sediment samples are listed and various ratios are calculated. Hydrocarbon and fatty acid concentrations are given relative to total organic carbon levels and to each other. Saturated hydrocarbon: TOC ratios appear to be related to distance from land in the Goderich Basin samples. This may be a result of sediment texture; that is. finer-sized sediments have greater total surface area and therefore can have more organic matter associated with them. Similarly, total fatty acid:TOC ratios decrease with distance to land in the Goderich Basin sediments. The dominant acid in most of these samples was palmitoleic acid $(16: 1)$. This is indicated by the ratio of this acid to palmitic acid (16:0) being greater than unity. which suggests a dominantly recent biological source of these fatty acids (Farrington and Quinn, 1971). Geolipid ratios in Saginaw Bay samples were relatively uniform, although average concentrations were higher than in the open lake.

The ratio of total normal fatty acids to total $n$-alkanes is also presented in Table 2. These two classes of compounds are biochemically related and therefore this ratio can be used to compare geolipid contents of different sediments. Most of the Goderich Basin samples have ratios between 8 and 10 , but the Saginaw Bay samples have ratios half this size. This implies that hydrocarbons are more important con- 


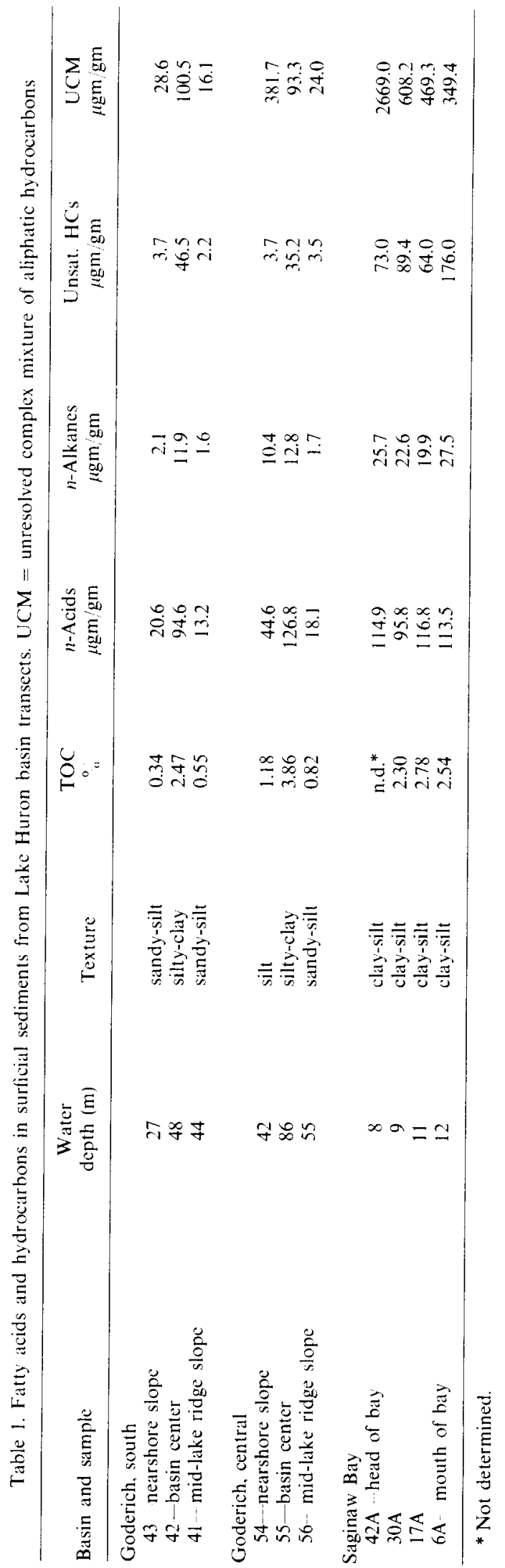




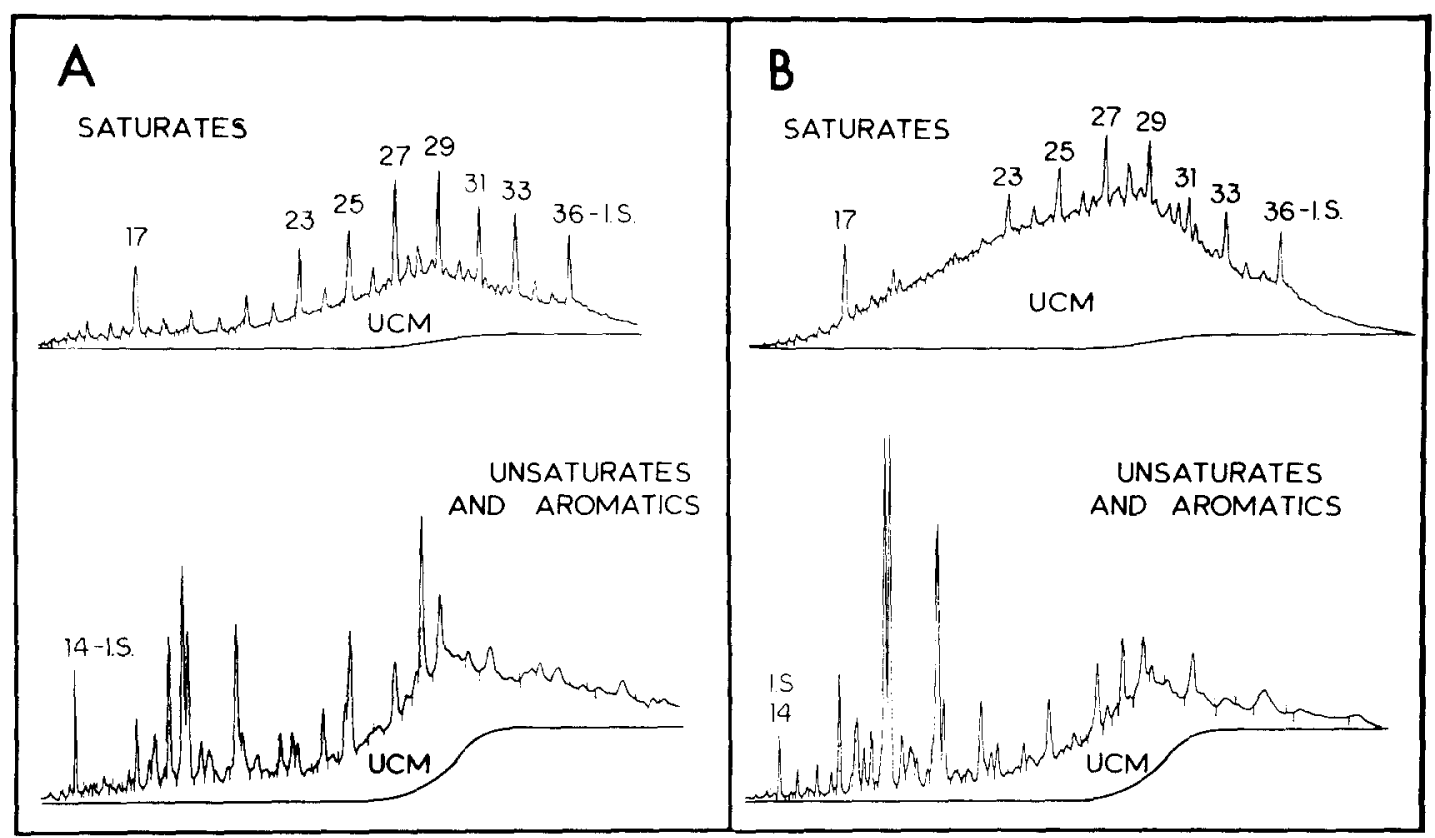

Fig. 2. Gas chromatograms of hydrocarbons from surficial sediments in Lake Huron. Normal alkanes are labeled by carbon numbers. Boiling point ranges of saturated and unsaturated fractions are similar. $\mathrm{A}=$ station 55 in Goderich Basin: $\mathrm{B}=$ station 30A in Saginaw Bay.

tributors to the total geolipid content of Saginaw Bay sediments than of Goderich Basin sediments.

\section{DISCUSSION}

In Goderich Basin, the concentrations of $n$-alkanes and fatty acids are highest in the silty-clay sediments of the deep center stations. However, as shown in Table 2 the total $n$-alkane:TOC and total fatty acids: TOC ratios decrease progressively from the nearshore slope locations to the mid-lake ridge locations. Accompanying this is a general decrease in the
16:1/16:0 fatty acid ratio which may indicate a change in the source of these materials. Such changes in the contribution of these geolipid consitutents to the total organic load of sediments with distance from shore imply a terrigenous origin for much of the $n$-alkanes and fatty acids, perhaps combined with alteration of these materials. In contrast, the ratio of total unsaturated hydrocarbons/TOC shows no similar trend and is instead highest in the basin-center stations within each transect (42 and 55) where organic carbon concentrations are highest. This suggests that most of these unsaturated hydrocarbons

Table 2. Ratios of organic components in Lake Huron surficial sediments

\begin{tabular}{|c|c|c|c|c|c|c|c|}
\hline Sample & $\begin{array}{l}\text { Distance from } \\
\text { shore }(\mathrm{km})\end{array}$ & $A$ & $\mathrm{~B}$ & $\mathrm{C}$ & $\mathrm{D}$ & $\mathrm{E}$ & $F$ \\
\hline \multicolumn{8}{|l|}{ Goderich Basin } \\
\hline 43 & 16 & 6.2 & 10.9 & 84.1 & 60.7 & 2.0 & 9.8 \\
\hline 54 & 15 & 8.8 & 3.1 & 323.5 & 37.8 & 2.1 & 4.3 \\
\hline 42 & 23 & 4.8 & 18.8 & 40.7 & 38.3 & 1.6 & 8.0 \\
\hline 55 & 28 & 3.3 & 9.1 & 24.2 & 32.8 & 2.2 & 9.9 \\
\hline 41 & 24 & 2.9 & 4.0 & 29.3 & 24.0 & 0.9 & 8.3 \\
\hline 56 & 35 & 2.1 & 4.2 & 29.3 & 22.1 & 1.6 & 10.7 \\
\hline \multicolumn{8}{|l|}{ Saginaw Bay } \\
\hline $42 \mathrm{~A}$ & 13 & $\ldots$ & $\ldots$ & - & --. & 1.4 & 4.5 \\
\hline $30 \mathrm{~A}$ & 17 & 9.8 & 38.9 & 264.4 & 41.7 & 1.5 & 4.2 \\
\hline $17 \mathrm{~A}$ & 10 & 7.2 & 23.0 & 168.8 & 42.0 & 1.5 & 5.9 \\
\hline $6 \mathrm{~A}$ & 6 & 10.8 & 69.3 & 137.6 & 44.8 & 1.4 & 4.1 \\
\hline
\end{tabular}

$A=$ total $n$-alkanes/total organic carbon ratio $\left(\times 10^{4}\right)$

$B=$ total polyunsaturated plus aromatic hydrocarbons/total organic carbon ratio $\left(\times 10^{4}\right)$.

$\mathrm{C}=$ unresolved complex mixture of aliphatic hydrocarbons/total organic carbon ratio $\left(\times 10^{4}\right)$.

$D=$ total fatty acids/total organic carbon ratio $\left(\times 10^{4}\right)$.

$\mathrm{E}=$ Palmitoleic acid concentration/palmitic acid concentration.

$\mathbf{F}=$ total acids/total $n$-alkanes. 
may not be directly derived from land sources and may be related to the amount of organic matter in the sediment, to sediment texture or mineralogy or to populations of aquatic organisms. As an example of the latter possibility, high levels of unsaturated hydrocarbons have been found in marine benthic organisms (Youngblood et al., 1971; Youngblood and Blumer, 1973: Meyers, 1977). It should be pointed out. however, that Thomas et al. (1973) could find no correlation between benthos concentration and organic carbon levels in the surficial sediments of Lake Huron, thus the source of unsaturated hydrocarbons is not obvious in these samples.

Figure 3 gives comparisons of fatty acid distributions in Goderich Basin surficial sediments which provide indications of several possible geolipid sources. All show a strongly biogenic pattern characterized by large amounts of saturated and unsaturated normal fatty acids with carbon chain-lengths of 14 , 16, and 18. These distributions lack the large contribution of longer-chain $n$-alkanoic acids found by Cranwell (1974) and Brooks et al. (1976) in several English Lakes. Such acids, from $\mathrm{C}_{22}$ to $C_{28}$, are indicative of land-derived organic matter while $C_{12}-C_{18}$ acids suggest aquatic sources (Cranwell, 1974). In- deed, the distributions found in the Lake Huron sediments resemble more closely fatty acid distributions reported by Cooper and Blumer (1968) and Farrington and Quinn (1973) for marine sediments than those described in English lakes. However, Matsuda and Koyama (1977) report a surficial sediment fatty distribution in Lake Suwa, Japan, which is very similar to the Lake Huron distributions shown in Fig. 3. It is probably that the dominant fatty acid sources in Lake Huron, as well as in Lake Suwa and the marine locations, are aquatic.

The abundance of monounsaturated acids such as palmitoleic and oleic shown in Fig. 3 gives support to an aquatic source of much of the acids in Lake Huron sediments. Palmitoleic acid has been found in relatively high levels in phytoplankton (Chuecas and Riley, 1969; Lewis, 1969; De Mort et al., 1972; Boutry and Barbier, 1974) and accompanying relatively high concentrations of oleic acid in sediment bacteria (Johns et al., 1977). In addition, the longer-chain $C_{22}$ unsaturated acid in the distributions in Fig. 3 is docosahexaenoic acid and may indicate a contribution of zooplankton lipids.

Longer-chain $n$-alkanoic acids characteristic of terrigenous sources (Brown et al., 1972; Cranwell, 1974,
TRANSECT I
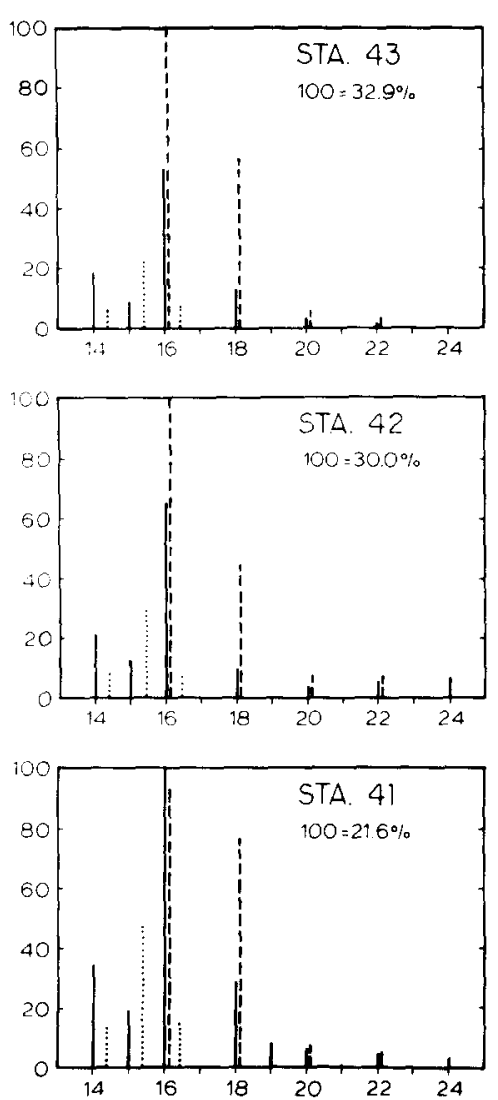

TRANSECT II

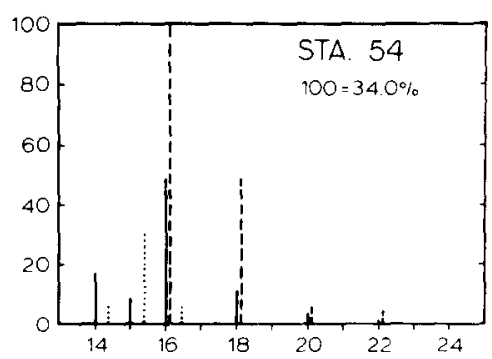

NEARSHORE

SLOPE

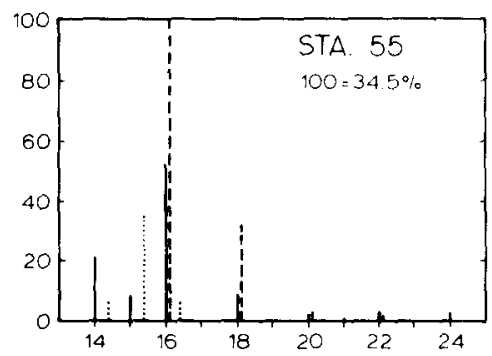

BASIN

CENTER

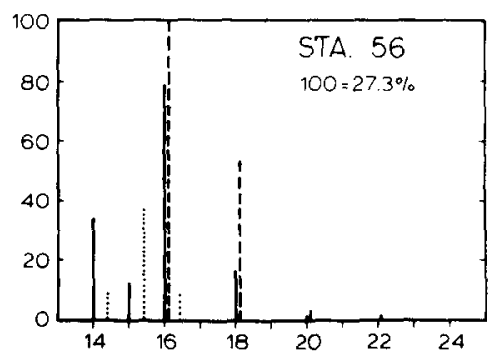

MIDLAKE

RIDGE

Fig. 3. Distributions of fatty acids in surficial sediment samples from two transects across the Goderich Basin of southern Lake Huron. Distributions normalized to major component. Solid line $=n$-alkanoic acid. dashed line $=n$-alkenoic acid, dotted line $=i$ so plus anteiso acid. See Table 1 and Fig. 1 for station locations. 
1977: Gaskell et al., 1975) are found, however, at stations 42 and 55 near the deepest parts of the Goderich Basin and at station 41 on the flank of a mid-lake subaqueous ridge. These acids could have been transported to the bottom of this basin associated with sediment particles originating from land run-off. Large amounts of $n$-alkanoic acids can be adsorbed by suspended sediments and longer-chain acids are preferentially adsorbed relative to shorterchain ones (Meyers and Quinn, 1973). Thus, transport from terrigenous sources and accumulation in the basin center can be used to explain the saturated $C_{22}$ and $C_{24}$ acids found at stations 42 and 55 and it is reasonable to expect a similar although perhaps much smaller accumulation at most Lake Huron locations.

Station 41. however, is on the sloping side of a mid-lake ridge. The surficial sediment at this location is sandy and is probably a glacial till (Thomas et al., 1973; Kemp et al., 1974). Therefore, this sediment may be considerably older than that at any of the other locations in this study which appear to be accumulating modern sediments. Matsuda and Koyama (1977) have found an increase in abundance of $C_{24}$ relative to $C_{16} n$-alkanoic acids which occurs with depth of burial in Lake Suwa sediments, suggesting preferential degradation of shorter-chain acids in sediments with time. It is possible that the presence of $\mathrm{C}_{22}$ and $\mathrm{C}_{24}$ saturated acids at station 41 is due to a loss of shorter-chain acids and an accompanying enhancement of the relative contribution of longerchain acids over time. In support of this possibility, only at station 41 is the ratio of palmitoleic acid (16:1) to palmitic acid (16:0) less than unity (Table 2). The preferential loss of unsaturated acids over time of burial is well-documented (Parker, 1967; Farrington and Quinn, 1971: Johnson and Calder, 1973; Farrington e't al. 1977; Sassen, 1977; Matsuda and Koyama, 1977). Hence, it is possible that the presence of longer-chain components in the $n$-alkanoic acid composition of this mid-lake station could be from diagenetic loss of shorter-chain compounds over time, rather than from modern transport and accumulation processes. However, it is also possible that the relatively smaller contribution of alkenoic acids to total acids at station 41 indicates less biological productivity in this region of Lake Huron (Cranwell, 1977).

Branched-chain iso and anteiso fatty acids are important in the distributions shown in Fig. 3. These lipids are abundant in sediment bacteria (Leo and Parker, 1966: Cooper and Blumer, 1968; Cranwell, 1973a. 1974; Johns et al., 1977) and their presence is indicative of microbial biomass and alteration products in sediments (Parker, 1967; Boon et al., 1975; Brooks et al.., 1977). In the two transects across the Goderich Basin, the proportion of iso plus anteiso $C_{14}, C_{15}$ and $C_{16}$ acids increases with distance from shore, and the proportion of monounsaturated acids decreases (Fig. 2.). Johnson and Calder (1973) found that an increase of branched acids and a decrease in unsaturated acids with depth or age of burial in a marsh sediment was caused by in situ microbial activity. The distributions found in these Lake Huron samples may result from (1) different benthic environments having characteristic microbial populations across the transect or (2) an increase in sediment transport time from land to each location and therefore in exposure to microbial alteration. While benthic environments probably are different, a progressive change such as seen in Fig. 3 suggests distance from land may be an important factor in the geolipid content of these sediments. Furthermore, sedimentation rates decrease with distance from land in these transects (J. A. Robbins, personal communication. 1977), indicating the mean surficial sediment sample age increases across the basin. The location having the slowest accumulation rate and therefore greatest mean sample age is station 41 , near mid-lake. This sample displayed the greatest amounts of branched fatty acids in Fig. 3. Thus, analysis of these transect samples leads to the conclusion that slower sedimentation rates contribute to greater microbial alteration of fatty acids associated with accumulating sediment particles.

Figure 4 shows that distributions of $n$-alkanes in surficial sediments from Goderich Basin are bimodal. Shorter-chain alkanes $\left(C_{15}-C_{19}\right)$ comprise one part of these distributions and longer-chain hydrocarbons $\left(\mathrm{C}_{25}-\mathrm{C}_{33}\right)$ the other. Shorter-chain alkanes, most prominently $n-\mathrm{C}_{17}$, are indicative of algal hydrocarbons (Clark and Blumer, 1967; Winters et al., 1969; Blumer et al., 1971; Youngblood et al., 1971; Giger and Schaffner, 1975; Paoletti et al., 1976). Thus, there is an important input of algal hydrocarbons. probably from within Lake Huron, to these sediments. The longer-chain portions of the alkane distribution are dominated by $\mathrm{C}_{25}, \mathrm{C}_{27}$ or $\mathrm{C}_{29}$ in the various samples. Higher plants typically have $n$-alkane maxima at $\mathrm{C}_{27}, \mathrm{C}_{29}$ or $\mathrm{C}_{31}$ (Douglas and Eglinton, 1966; Cranwell, 1973b; Giger and Schaffner. 1975 ) and exist as land or as emergent aquatic species. Freshwater zooplankton distributions commonly are from $C_{23}$ to $C_{27}$ peaking at $C_{25}$ (Giger and Schaffner, 1975). Combination of these two very likely sources would provide the longer-chain $n$-alkane distributions shown in Fig. 4, and addition of an algal hydrocarbon component would give the overall patterns found in these sediments.

Although differences exist among the distributions in Fig. 4, the similarity of all six is striking. Evidently, all $n$-alkanes added to the sediments of southern Lake Huron have common or very similar origins, even though concentrations both absolute and relative to total organic carbon decrease with distance from land (Tables 1 and 2). Differences in fatty acid distributions are found in these sediment samples (Fig. 3) and are best explained by alteration of biological source materials. Therefore, the lack of differences in n-alkane distributions supports the general view of 

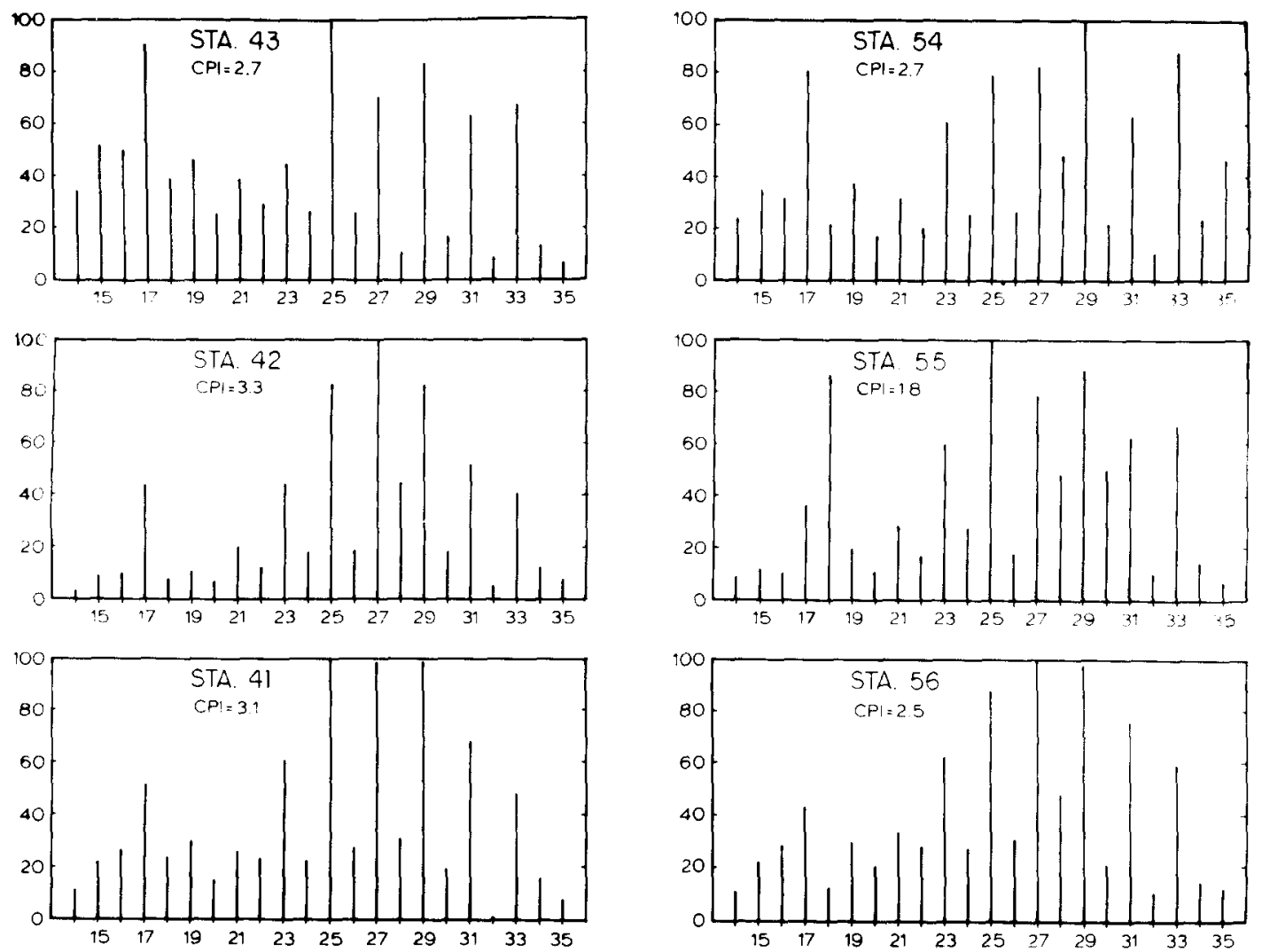

Fig. 4. Distributions of $n$-alkanes in surficial sediment samples from two transects across the Goderich Basin of southern Lake Huron. Distributions normalized to major component. See Table 1 and Fig. 1 for station locations. CPI = Carbon Preference Index (Cooper and Bray. 1963).

the more refractory nature of hydrocarbons relative to acids.

It is interesting to compare the $n$-alkane distributions in Fig. 4 to those found in other surficial sediments. The contribution of longer-chain components representative of a terrigenous input is less in these Lake Huron samples than in the sediments of Blelham Tarn, an oligotrophic English lake (Cranwell, 1973b) of Grasmere, a moderately productive English lake (Brooks, et al., 1976) and of Lake Quinault, an oligotrophic lake in Washington, U.S.A. (Wakeham, 1976). Coastal marine sediments receiving large amounts of land-derived organic material have $n$-alkane distributions characterized by longer-chain components (Gaskell et al., 1975; Gearing et al.. 1976; Brooks et al., 1976) and contain proportionally more $\mathrm{C}_{27}, \mathrm{C}_{33}$ n-alkanes than do these Lake Huron sediments. Although not dominated by long-chain hydrocarbons, the n-alkane distributions are also not strongly skewed towards shorter components. The relative amounts of $C_{15}-C_{19} n$-alkanes is less than in sediments from Rostherne Mere in England (Brooks et al., 1976), Lake Sammamish in the state of Washington (Wakeham, 1976), the Greifensee in Switzerland (Giger and Schaffner, 1975) and Mono Lake in California (Reed, 1977). These lakes, all eutrophic, have high algal populations and $n$-alkane distributions in their sediments which are dominated by n-heptadecane. Similar distributions have been reported for marine areas believed to be dominated by an algal source of organic matter (Gearing et al., 1976; Palacas et al., 1976).

Sediment $n$-alkane distributions of Goderich Basin most closely resemble those reported for Esthwaite Water in England (Brooks et al, 1976) and Lake Washington (Wakeham and Carpenter, 1976). Both these lakes are highly productive and receive considerable runoff from their drainage basins. However, the Goderich Basin of southern Lake Huron is neither highly productive nor receives large amounts of runoff relative to its volume. resulting in lower absolute amounts of total organic carbon and geolipids in its sediments compared to these two lakes. It is interesting that these three lakes have such similar $n$-alkane distributions, evidently from similar proportions of input materials even though absolute concentrations differ. These proportions can change with time, as shown by Wakeham and Carpenter (1976) in Lake Washington where less productive aquatic conditions are recorded deeper in the sediment by a relative decrease in shorter-chain $n$-alkane contributions as well as decreases in concentrations of total aliphatic hydrocarbons and organic carbon.

Carbon preference indices (Cooper and Bray, 1963) of the six Goderich Basin samples are fairly high, reflecting large amounts of recently biosynthesized 
higher plant material in the $n$-alkane distributions. These values. between 1.8 and 3.3 , are similar to those reported for uncontaminated modern sediments from both marine (Clark and Blumer, 1967) and freshwater environments (Cranwell. 1973b: Brooks et al., 1976; Wakeham and Carpenter, 1976). Evidently, the large size of Lake Huron has protected this portion of it from demonstrable impacts of urbanization similar to those shown for Lake Washington (Wakeham and Carpenter, 1976: Wakcham. 1976. 1977a.b) and Lake Zug (Giger 't al. 1974).

In surficial sediments from Saginaw Bay, concentrations both of n-alkanes and unsaturated hydrocarbons shown in Table 1 are about twice as high as in those of similar total organic carbon levels in the Goderich Basin (stations 42 and 55), yet fatty acid levels are comparable in both locations. Ratios of these geolipid components to total organic carbon reveal no strong trends within the Saginaw Bay sampling transect, although station $6 \mathrm{~A}$ which is closest to land has higher ratios than the other Saginaw Bay stations. These observations are consistent with the suggestion that n-alkanes may be to a large extent land-derived, because all locations within Saginaw Bay are intuenced by land runoff via the Saginaw River (Fig. 1). Furthermore, the data in Table 1 from Saginaw Bay are also consistent with the idea that unsaturated hydrocarbons are related to organic matter or sediment character rather than being from terrigenous sources because all the Saginaw Bay samples are similar to station 42 and 55 in Goderich Basin in these parameters. However, the absence of enhanced fatty acid amounts expressed as either con-
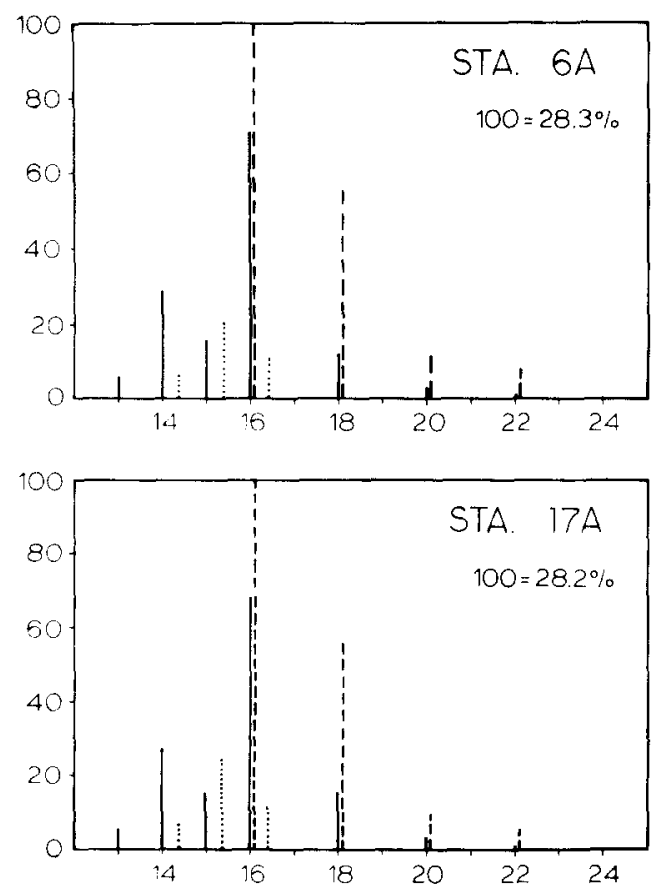

centrations within the sediments or as ratios to organic carbon levels implies an additional source of both saturated and unsaturated hydrocarbons in Saginaw Bay. This may be from a combination of land runoff containing hydrocarbons and of different biological communities in the waters and sediments of the Bay as compared to the open lake.

The fatty acid distributions in Saginaw Bay sediments shown in Fig. 5 are very similar to each other. Relative amounts of $n$-alkanoic acids are the same in stations 6A, 17A. and 30A and differ only due to the appearance of longer-chain acids in station $42 \mathrm{~A}$. The latter station is closest to the mouth of the Saginaw River (Fig. 1 ) and undoubtedly receives more land-derived organic material than the other stations from this large river and its watershed. The ratio of palmitoleic to palmitic acid in the four samples is quite consistent (Table 2), further reflecting similar fatty acid compositions. Furthermore, the contribution of branched acids is virtually the same in all samples of Bay sediment. These distributions differ from those in the open-lake samples (Fig. 3) in having lower amounts of branched acids and in their uniformity.

As indicated by sediment texture descriptions and TOC concentrations in Table 1 and by the ratio of total fatty acids to TOC in Table 2, the sedimentary environment appears to be fairly uniform in Saginaw Bay. This is probably the result of sediment particle dispersion within this shallow and well-mixed bay. While surficial sediment grain size does vary in Saginaw Bay (Wood. 1964), the mean size distribution of the four locations sampled in this study is between
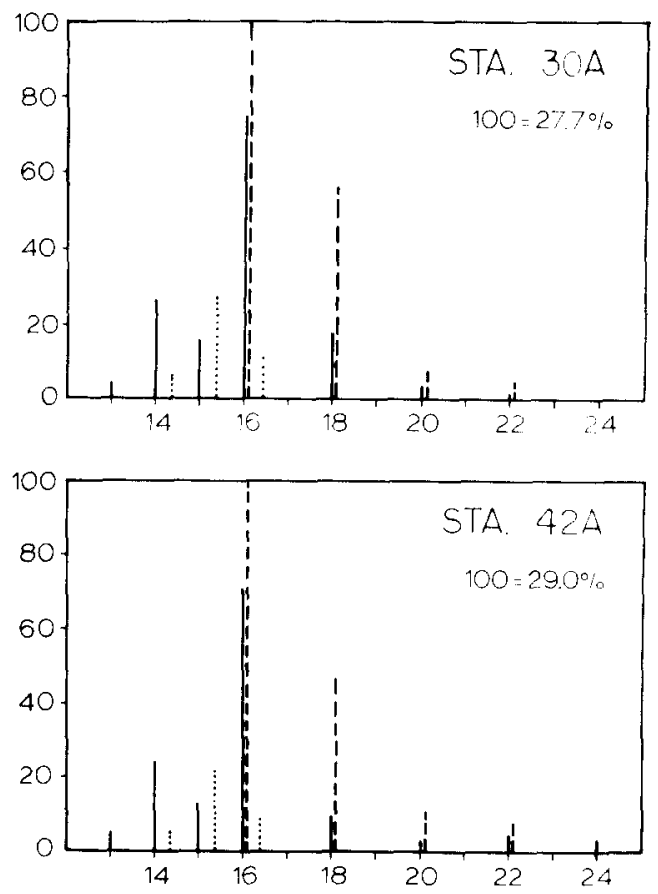

Fig. 5. Distributions of fatty acids in surficial sediment samples from Saginaw Bay of Lake Huron. See legend of Fig. 3. 

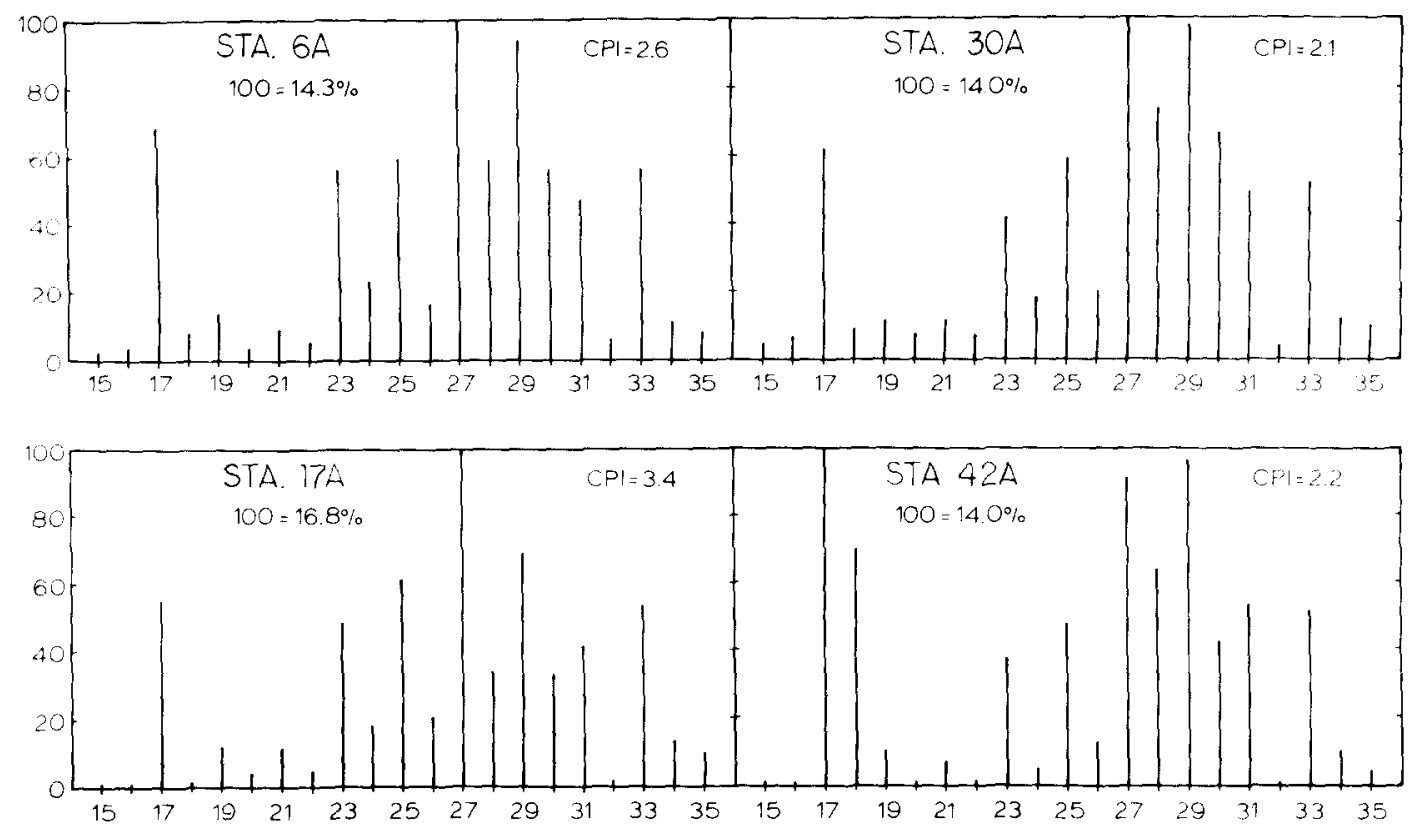

Fig. 6. Distributions of $n$-alkanes in surficial sediment samples from Saginaw Bay of Lake Huron. See legend of Fig. 4.

5.5 and 6.0 phi units (E. Seibel, personal communication, 1977). Lipid material can become strongly associated with suspended sediment particles (Meyers, 1972; Shaw, 1973) and thus processes causing transport and distribution of sediment particles will also disperse associated lipids such as fatty acids and hydrocarbons and contribute towards their uniform deposition.

Normal alkane patterns in the Bay sediments are also affected by deposition of well-mixed sediments. As shown in Fig. 6, the distributions at stations 6A. $17 \mathrm{~A}$, and $30 \mathrm{~A}$ are very similar and the distribution at station $42 \mathrm{~A}$ is only slightly different. All locations have bimodal distributions maximized at $C_{17}$ and at $\mathrm{C}_{27}$ or $\mathrm{C}_{29}$. Contributions of $\mathrm{C}_{25}$ are less than in the open-lake sediment distributions in Fig. 4, but amounts of $\mathrm{C}_{33}$ are high at both Saginaw Bay stations and near-shore Goderich Basin stations (43 and 54). Major sources of $n$-alkanes to the Saginaw Bay sediments appear to be algal and higher plant. with zooplankton contributing a smaller amount relative to the open-lake.

An unresolved envelope of aliphatic hydrocarbons underlying the resolved $n$-alkane peaks is present in large amounts in the Saginaw Bay surficial sediment hydrocarbons (Fig. 2). Combined gas chromatography mass spectrometry of the UCM has revealed it to be $85 \%$ cyclic alkanes (R. A. Brown, personal communication, 1976). The Saginaw Bay UCMs are comparable to one reported for Lake Sammamish sediments by Wakeham (1976), whereas in Goderich Basin sediments they are similar to one in pristine Lake Quinault. Because the presence of a UCM is considered diagnostic of petroleum contamination (Shaw, 1973; Palacas et al., 1976: Gearing et al.. 1976;
Wakeham, 1976, 1977a,b; Wakeham and Carpenter. 1976; Farrington and Tripp, 1977), it is likely that Saginaw Bay sediments contain petroleum-derived hydrocarbons. These could be introduced into the Bay by urban runoff from the industrial cities along the Saginaw River and its tributaries. and this possibility is consistent with the higher hydrocarbon-to-TOC ratios of Bay sediments relative to Goderich Basin sediments in Table 2.

However, the bimodal distributions in Fig. 6 strongly suggest a recent biological source of the n-alkanes in Saginaw Bay, and the CPI values of 2.1-3.4 are not as low as would be expected for weathered petroleum, for which these would be closer to unity. Evidently, the saturated hydrocarbons exist as a mixture of resolved, recently biosynthesized compounds and unresolved, weathered hydrocarbons. This is not surprising. It is probable that during weathering a preferential loss of resolved hydrocarbons occurred as shown by Bailey et al. (1973) for bacterial degradation of crude oil, leaving a UCM. In addition to petroleum hydrocarbons, it is possible that other sources. such as weathered hydrocarbons from erosion of geological formations. microbial synthesis and industrial effluents, may have contributed to the hydrocarbon mixture in Saginaw Bay sediments. Ongoing investigations of hydrocarbon distributions with depth should provide more information about these possibilities.

\section{CONCLUSIONS}

(1) Fatty acids and resolved hydrocarbons in surficial sediments from ten locations in Lake Huron give clear evidence of a recent biogenic origin. Both aqua- 
tic and terrigenous sources are indicated. (2) The dominant fatty acid sources appear to be aquatic and are probably algal and microbial in type whereas n-alkane distributions have a significant terrigenous component. This suggests that the more refractory hydrocarbons experience greater amounts of transport and dispersion than do the more labile fatty acids. Transport appears to occur in association with suspended sediment particles. (3) Sediment geolipid content varies across sedimentary basins. This may be due to changes in sediment texture, patchiness in benthic communities, geochemical microenvironments, variations in source materials, or different transport times and routes. Many of these parameters are interrelated and their effects cannot be isolated. This conclusion agrees with the findings of Reed (1977). (4) Saginaw Bay surficial sediments appear to receive a significant anthropogenic input of petroleum-derived or industrially produced hydrocarbons, possible via urban runoff and effluents.

Acknowledgements We thank J. W. FarRINGTON and J. G. Palaras for their helpful comments on this manuscript. R. A. Brown of Exxon Research and Production Company kindly provided combined GC-MS analysis of several extracts. $R$. A. BOt RBONNIERE contributed much in developing laboratory and data analysis procedures. Financial support of this research was from the U.S. Environmental Protection Agency Large Lakes Laboratory and the Rackham School of The University of Michigan.

\section{REFERENCES}

Bailey, N. J. L., Jobson, A. M.. and Rogers, M. A., 1973 , Bacterial degradation of crude oil: comparison of field and experimental data: Chem. Geol, v. 11, p. 203-221.

Blumer, M.. 1957, Removal of elemental sulfur from hydrocarbon fractions: Anal. Chem. v. 29. p. 1039-1041.

Blumer. M.. Guillard. R. R. L., and Chase, T., 1971, Hydrocarbons of marine phytoplankton: Mar. Biol. v. 8, p. 183189.

Boon. J. J.. deleeuw, J. W., and Schenck, P. A., 1975. Organic geochemistry of Walvis Bay diatomaceous ooze--1. Occurrence and significance of the fatty acids: Geochim. Cosmochim. Acta. v. 39, p. 1559-1565.

Boutry. J. L.. and Barbier. M., 1974, La diatomée marine Chatoceros simplex calcitrans Paulsen et son environment-I. Relations avec le milieu de culture: étude de la fraction insaponifiable des stérols et des acides gras: Mar. Chem. v. 2, p. 217-227.

Brooks, P. W.. Eglinton, G., Gaskell, S. J., McHugh, D. J.. Maxwell. J. R., and Philp, R. P.. 1976, Lipids of recent sediments. part I. straight-chain hydrocarbons and carboxylic acids of some temperate lacustrine and subtropical lagoonal/tidal flat sediments: Chem. Geol. v. 18 . p. $21 \cdots 38$.

Brooks. P. W.. Eglinton. G.. Maxwell, S. J., McHugh, D. J. Maxwell, J. R., and Philp, R. P., 1977, Lipids of recent sediments. Part II. Branched and eyclic alkanes and alkanoic acids of some temperate lacustrine and subtropical lagonnal/tidal-flat sediments: Chem. Geol., v. 20 , p. 180-204.

Brown. F. S., Baedecker, M. J., Nissenbaum, A., and Kaplan. I. R.. 1972. Early diagenesis in a reducing fjord, Saanich Inlet. British Columbia-III. Changes in organic constituents of sediment: Geochim. Cosmochim. Acra. v. 36. p. $1185-1203$.
Chuecas, L., and Riley, J. P., 1969, Component fatty acids of total lipids of some marine phytoplankton: $J$. Mar. Biol. Ass. U.K., v. 49, p. 97-116.

Clark, R. J., Jr., and Blumer, M., 1967, Distribution of $n$-paraffins in marine organisms and sediment: Limnol. Oceanogr., v. 12, p. 79-87.

Cooper, J. E., and Bray, E. E., 1963, A postulated role of fatty acids in petroleum formation: Geochim. Cosmochim. Acta, v. 27, p. 1113-1127.

Cooper, W. J., and Blumer M., 1968, Linear, iso and anteiso fatty acids in Recent sediments of the North Atlantic: Deep-Sea Res., v. 15, p. 535-540.

Cranwell, P. A., 1973a, Branched-chain and cyclopropannid acids in a recent sediment: Chem. Geol., v. 11. p. $307-313$.

Cranwell, P. A., 1973b, Chain-length distribution of $n$-alkanes from lake sediments in relation to post-glacial environmental change: Freshwater Biology, v. 3. p. 259 265.

Cranwell, P. A., 1977, Organic geochemistry of Cam Loch (Sutherland) sediments: Chem. Geol, v. 20, p. 205-221

Cranwell, P. A., 1974, Monocarboxylic acids in lake sediments: indicators, derived from terrestrial and aquatic biota of paleoenvironmental trophic levels: Chem. Geol. v. 14, p. $1-14$.

DeMort, C. L., Lowry, R., Tinsley, I., and Phinney, H. K., 1972. The biochemical analysis of some estuarine phytoplankton species-I. Fatty acid composition: $J$. Phycol., v. 8, p. 211-216.

Douglas, A. G., and Eglinton, G., 1966, The distribution of alkanes, in Swain, T., ed., Comparative Phytochemistry, Academic Press, p. 187-218.

Farrington, J. W., Henrichs, S. M., and Anderson, R., 1977. Fatty acids and ${ }^{210} \mathrm{~Pb}$ geochronology of a sediment core from Buzzards Bay, Massachusetts: Geochim. Cosmochim. Acta, v. 41, p. 289-296.

Farrington, J. W., and Quinn, J. G., 1971, Comparison of sampling and extraction techniques for fatty acids in recent sediments: Geochim. Cosmochim. Acta, v. 35. p. $735-741$

Farrington, J. W., and Quinn, J. G., 1973, Biogeochemistry of fatty acids in Recent sediments from Narragansett Bay, RI: Geochim. Cosmochim. Acta, v. 37, p. 259-268. Farrington, J. W., and Tripp, B. W., 1977, Hydrocarbons in western North Atlantic surface sediments: Geochim. Cosmochim. Acta, v. 41, p. 1627-1641.

Gaskell, S. J., Morris, R. J., Eglinton, G., and Calvert, S. E., 1975. The geochemistry of a recent marine sediment off northwest Africa. An assessment of source of input and early diagenesis: Deep-Sea Research, v. 22, p. 777 789 .

Gearing, P., Gearing, J. N., Lytle, T. F., and Lytle, J. S., 1976, Hydrocarbons in 60 northeast Gulf of Mexico shelf sediments: a preliminary survey: Geochim. Cosmochim. Acta, v. 40, p. $1005-1017$.

Giger, W., Reinhard, M.. Schaffner, C., and Stumm, W. 1974, Petroluem-derived and indigenous hydrocarbons in recent sediments of Lake Zug, Switzerland: Environ. Sci. Technol., v. 8, p. 454-455.

Giger, W., and Schaffner, C., 1975, Aliphatic, olefinic, and aromatic hydrocarbons in recent sediments of a highly eutrophic lake: Adv. Org. Geochem., 1975, p. 375-390.

Hough, J. L., 1958, Geology of the Great Lakes. University of Illinois Press, Urbana, $313 \mathrm{pp}$.

Johns, R. B., Perry, G. J., and Jackson, K. S., 1977, Contribution of bacterial lipids to recent marine sediments: Est. Coastal Mar. Sci., v. 5, p. 521-529.

Johnson, R. W., and Calder, J. A., 1973, Early diagenesis of fatty acids and hydrocarbons in a salt marsh environment: Geochim. Cosmochim. Acta, v. 37, p. 1943-1955.

Keizer, P. D., Dale, J., and Gordon, D. C.. Jr., 1978. Hydrocarbons in surficial sediments from the Scotian Shelf: Geochim. Cosmochim. Acta, v. 42, p. 165-172. 
Kemp. A. L. W. Anderson, T. W., Thomas, R. L., and Mudrochova. A., 1974, Sedimentation rates and Recent sediment history of Lakes Ontario, Erie, and Huron: J. Sed. Petrology, v. 44, p. 207-218.

Leo. R. F., and Parker, P. L., 1966, Branched-chain fatty acids in sediments: Science, v. 152, p. 649-650.

Lewis, R. W., 1969, The fatty acid composition of arctic marine phytoplankton and zooplankton with special reference to minor acids: Limnol. Oceanogr., v. 14. p. $35-40$.

Matsuda, H., and Koyoma, T.. 1977, Early diagenesis of fatty acids in lacustrine sediments -I. Identification and distribution of fatty acids in recent sediment from a freshwater lake: Geochim. Cosmochim. Acta, v, 41, p. 777-783

Metcalfe. L. D., Schmitz. A. A., and Pelka. J. R.. 1966, A rapid preparation of fatty acid esters from lipids for gas chromatographic analysis: Anal. Chem., v. 38, p. 514 515

Meyers P. A., 1972. Association of fatty acids and hydrocarbons with mineral particles in sea water. Ph.D. Thesis, Univ. Rhode Island, $155 \mathrm{pp}$.

Meyers, P. A., 1977. Fatty acids and hydrocarbons of Caribbean corals. In, Taylor, D. L., ed., Proceedings, Third International Coral Reef Symposium. Vol. 1. p. $529-536$

Mevers, P. A., and Quinn, J. G., 1973, Factors affecting the association of fatty acids with mineral particles in sea water: Grochim. Cosmochim. Acta, v. 37. p. 17451759.

Palacas, J. G.. Gerrild, P. M., Love, A. H., and Roberts, A. A., 1976, Baseline concentrations of hydrocarbons in barrier-island quartz sand, northeastern Gulf of Mexico: Geologv. v. 4, p. 8I-84.

Paoletti, C.. Pushparaj, B., Florenzano, G., Capella, P., and Lereker, G., 1976, Unsaponifiable matter of green and blue-green algal lipids as a factor of biochemical differ- entiation of their biomass--1. Total unsaponifiable and hydrocarbon fraction: Lipids, v. 11. p. 258-265.

Parker, P. L., 1967, Fatty acids in Recent sediment: Contr. Mar. Sci. v. 12 , p. $135 \cdots 142$.

Reed, W. E., 1977. Biogeochemistry of Mono Lake, California: Geochim. Cosmochim. Acta. v. 41, p. 1231 . 1245

Sassen, R., 1977. The fate of fatty acids from corals and mangroves in Holocene sediments of St. Croix: significance with respect to petroleum genesis. In Taylor, D L., ed., Proceedings, Third International Coral Reef Symposium, Vol. 2, Univ. Miami. p. 134-14!.

Shaw, D. G.. 1973, Lipids in shallow bottom sediments. Ene: Sci. Technol., v. 7. p. 740-742.

Thomas, R. L., Kemp, A. L. W. and Lewis, C. F. M. 1973. The surficial sediments of Lake Huron: Can. J. Earth Sci., v. 10, p. $226-271$.

Wakeham, S. G., 1976, A comparative survey of petroleum hydrocarbons in lake sediments: Mar. Pollut. Bull., v. 7 , p. $206-211$

Wakeham, S. G. 1977a, A characterization of the sources of petroleum hydrocarbons in Lake Washington: $J$. Water Poll. Control Fed., v. 49. p. 1680-1687.

Wakeham. S. G., 1977b, Hydrocarbon budgets for Lake Washington: Limmol. Oceanogr. v. 22. p. 952-957.

Winters, K., Parker, P. L., and Van Baalen. C.. 1969. Hydrocarbons of blue-green algae: geochemical significance: Science, v. 163 , p. $467-468$.

Wood. L. E., 1964. Bottom sediments of Saginaw Bay, Michigan: J. Sediment. Petrol., v. 34, p. 175-184.

Youngblood, W. W., Blumer, M., Guillard, R. K., and Fiore, F. 1971, Saturated and unsaturated hydrocarbons in marine benthic algae: Mar. Biol., v. 8, p. $190-201$.

Youngblood, W. W.. and Blumer, M.. 1973. Alkanes and alkenes in marine benthic algac Mar. Biol., v. 21, p. $163+172$. 